\title{
Lenguaje poético e identidad negra: dos representaciones de la herencia africana en la poesía colombiana de los años $40^{1}$
}

\author{
Andrea Milena Guardia Hernández \\ Doctora en Lenguas, Letras y Traductología \\ Université catholique de Louvain, Louvain-la-Neuve, Bélgica \\ https://orcid.org/0000-0002-8831-7496 \\ andrea.guardia@uclouvain.be \\ Cindy Paola Torres Salazar \\ Licenciada en Humanidades y Lengua Castellana \\ Universidad La Gran Colombia, Bogotá, Colombia \\ https://orcid.org/0000-0001-6069-8541 \\ CTORRESS1@ulagrancolombia.edu.co
}

\section{Resumen}

La literatura afro en América Latina es un fenómeno que exige la comprensión de la identidad racial como un constructo fluido, multidimensional y social, el cual tiene lugar como una performance que, en su plasticidad, asume diferentes facetas. Los poemarios Evangelios del hombre y del paisaje, de Helcías Martán Góngora, y Tambores en la noche, de Jorge Artel, despliegan dos aspectos de la afrocolombianidad en la poesía hispanoamericana de la primera mitad del siglo XX. Haciendo uso de un lenguaje poético de tradición hispana y de corte piedracielista, ambos autores recurren a la herencia africana en un ejercicio identitario de alcances colectivos y fraternales, asumiendo dos posturas diferentes ante el proceso contencioso de la identidad afro en el espacio hegemónico andino colombiano.

Palabras clave: Afrocolombianidad; identidad racial; literatura afro; piedracielismo; poesía hispanoamericana.

1 Procedencia del artículo: Este artículo es resultados de una investigación personal. 


\title{
Poetic language and black identity: Two representations of African heritage in Colombian poetry of the 40 s
}

\begin{abstract}
Afro-hispanic literature in Latin America is a phenomenon that demands the understanding of racial identity as a fluid, multidimensional and social construct which takes place as a plastic performance with different facets. The poems in Evangelios de hombre y del paisaje by Helcías Martán Góngora and Tambores en la noche by Jorge Artel deploy two ways of presenting afrocolombianity in Hispanic American poetry at the beginning of the 20th century. Using a poetic language of Spanish tradition and a "piedracielista" tone, both authors turn to African heritage in the display of an identity that aims for a collective and fraternal reach. In doing so, they take two different stances when facing the contentious process of an African-rooted identity in the hegemonic space of Andean Colombia.
\end{abstract}

Keywords: Afrocolombianity; afro-hispanic literatura; Hispanic American poetry; piedracielismo; racial identity.

Recibido: 14 de agosto del 2020. Hprobado: 23 de septiembre del 2020

Artículo de reflexión https://doi.org/10.25100/poligramas.v0i51.10894

¿Cómo citar este artículo en MLH? - How to quote this article in MLH?

Guardia Hernández, Andrea M. y Cindy P. Torres Salazar. "Lenguaje poético e identidad negra: dos representaciones de la herencia africana en la poesía colombiana de los años 40" Poligramas 51 (2020): n. pag. Web. Fecha de acceso (día, mes en mayúscula y abreviado, y año). 
Negro soy desde hace muchos siglos.

Jorge Artel

Turbio cóctel de tres estirpes soy.

Helcías Martán Góngora

Acercarse a la literatura afro implica de partida la pregunta por la relación entre identidad, raza y literatura. ¿Cuál sería la base para elegir un corpus que responda a esta categoría? ¿La condición racial de su autor? ¿La de sus personajes? ¿O quizás la temática de la reivindicación de una raza? El adjetivo afro condensa una compleja red de interacciones sociales y culturales que tiende a ser naturalizada y esencializada, de manera que pareciera evidente que, como señala Prescott, "la literatura afrocolombiana es aquella escrita por autores de origen africano" (Evaluando... 554). No obstante, lo que significa este origen africano parece quedar fuera del cuestionamiento, olvidando que el arraigo racial y étnico hace parte de un ejercicio de la identidad que incluye la interacción y el reconocimiento individual y colectivo de la pertenencia.

La identidad surge como problema cuando el sentido de pertenencia de una persona se ve perturbado (Preece 2). De allí que toda afirmación identitaria sea un proceso contencioso y, como tal, implique un acto de subjetivación escenificado en un campo en disputa. La identidad, entendida como la comprensión de la relación de un individuo con el mundo a través del tiempo y el espacio, es un constructo fluido, multidimensional y socialmente construido (Preece 2). La identidad es performativa en la medida en que implica la puesta en acto de los modos en que el individuo, en su diversidad, se posiciona en cierto contexto frente a otros, desde facetas como el género, la sexualidad, la raza, la etnia, la edad, la religión, etc. En el caso concreto de la literatura afrocolombiana, la identidad racial debe ser abordada como problema y no como una categoría natural o biológica. Haney-López define la raza como:

un vasto grupo de personas relacionadas de manera imprecisa por elementos históricamente contingentes y socialmente significativos derivados de su morfología o sus ancestros. (...) No es una esencia ni una ilusión, sino más bien un proceso plástico y permanente de carácter contradictorio y auto-afirmativo sujeto a las macrofuerzas sociales de la lucha social y política y a los microefectos de las decisiones diarias (ctd. en Omoniyi 147 [traducción nuestra]). 
En este marco, el adjetivo afrodescendiente calificaría a una comunidad socialmente construida que está determinada por el gesto simbólico y performativo de inclusión que lleva a cabo un individuo. También, esta comunidad puede configurarse por una identidad adscrita (Preece 3), es decir, no por la autoafirmación, sino por la atribución externa con base en rasgos físicos o culturales institucionalizados o estereotipados. En lo que corresponde a las comunidades afrodescendientes, su unidad estaría determinada, como se pronuncia en la declaración de la Conferencia mundial contra el racismo, la discriminación racial, la xenofobia y las formas conexas de intolerancia realizada por las Naciones Unidas en el 2001, por tres condiciones: la condición diaspórica que las une con el continente africano; la desigualdad que sufren en el acceso a la salud, educación y el empleo; y la necesidad de reconocimiento de la riqueza de su patrimonio cultural y de sus aportes a las zonas de acogida. Estas comunidades comparten, así, un "origen (África), una historia (la trata) y unas raíces étnicas y ancestrales" (Valero 25).

El adjetivo "afrodescendiente», entonces, se consolida como producto de una discusión pública que tiene lugar a finales del siglo XX respecto de la constitución de una población americana que parecía borrar, bajo su mestizaje, una serie de violencias raciales aún vigentes. Este adjetivo reemplazaría la clasificación colonial de "negro», un término asociado a la naturalización de una jerarquía social, y pone el énfasis "en la diáspora, la cimarronería y en las luchas de resistencia" (Oliva 53). En el caso de Colombia, la Ley 93 de 1993 institucionalizó la condición de ascendencia afro de las comunidades negras, con lo que se creó la categoría de "afrocolombiano» y se abrió la reflexión sobre los modos en que esta etiqueta se relaciona con la identidad adscrita o autoafirmada. La génesis reciente de la categoría "afrocolombiano» justifica el señalamiento de Valero, quien acierta al considerar que "la categoría de literatura afrocolombiana es una categoría performativa [pues] crea lo que nombra" (27). En otras palabras, solo en la medida en que lo afrocolombiano surge como denominación de un campo que ahora es "decible" (Valero 26), es posible aplicar esta categoría a diferentes producciones culturales, entre ellas la literaria. Y en el momento en que se realiza el gesto de asignar esta categoría a un corpus específico, el crítico crea un conjunto de textos que él agrupa a partir de una identidad adscrita.

La categoría de «literatura afrocolombiana» abre un campo que puede nombrarse y pensarse recién a finales del siglo XX y cuya consolidación crítica se da apenas a principios del 
XXI (Valero 16). Esto explica la inexistencia de una sección dedicada a esta literatura en la mayoría de las antologías y listas canónicas de textos literarios emblemáticos, exclusión que preocupa a la mayoría de los comentaristas (Capote 86; Lawo-sukam, Acercamiento... 41; Prescott Evaluando... 554; Prescott Perfil histórico... 112-113). Siguiendo los caminos abiertos por lo afrocolombiano como campo pensable y decible, se hace necesario examinar la producción literaria desde esta perspectiva para analizar los rasgos intratextuales y las condiciones extratextuales que se configuran en torno a la raza y a lo afro, un ejercicio crítico que hace parte del proceso histórico y social de reconocimiento del dinamismo de la diversidad racial y étnica de los territorios. Pensar una obra desde el problema de la identidad racial autoafirmada o adscrita potencializa el lugar del texto literario como espacio simbólico de intersecciones y negociaciones que desborda la dicotomía negro-blanco (Valero 33). En él puede operar la identidad racial como cruce entre lo corporal, la espacialidad y la pertenencia y diferencia, la cual se pone en acto en el lenguaje (Omoniyi 147). Desde allí, puede pensarse lo afro en la literatura como la solidaridad con un pasado de sufrimiento (Jackson ctd. en Valero 18), el despertar de la voz del negro y su conciencia racial (Lawo-Sukam Acercamiento... 41), el regreso mítico a África como celebración identitaria (47), el desequilibrio de espacios hegemónicos (51), o la responsabilidad de develar al mundo un pueblo (Prescott Evaluando... 556). Todo esto sin dejar de lado que no se trata del destino natural de una comunidad homogénea, sino de una negociación, una escenificación identitaria y, por lo tanto, contenciosa.

Con este objetivo, se propone un acercamiento a Evangelios del hombre y del paisaje (1944), de Helcías Martán Góngora, y Tambores en la noche (1940), de Jorge Artel, dos poemarios que abordan la cuestión racial en el contexto colombiano de principios del siglo XX y que asumen dos miradas diferentes, aunque consonantes, frente a la autoafirmación y recuperación del componente afro en la identidad nacional. Este gesto identitario responde a un contexto de exclusión, pues Colombia, una nación formada sobre cimientos coloniales, lleva en su entraña histórica la desigualdad racial, social y regional de sus habitantes y su territorio. Las construcciones raciales de finales del siglo XIX están basadas en el pensamiento colonialista que se había desarrollado desde el siglo XVI. La ley colonial otorgaba la condición de «blanco» a unos pocos y esta categorización iba acompañada de los privilegios propios de un linaje noble, por lo que la distinción racial derivó en un sistema socioeconómico en el que ser identificado con una raza implicaba un determinado estatus social. A pesar del rechazo de la Corona a las 
uniones interraciales (Prescott, Without hatred... 29), la mezcla racial en Colombia durante el periodo colonial trajo como resultado la difuminación de límites precisos entre negros, blancos e indígenas. De este modo, la piel más clara y los rasgos más europeos de un sujeto mestizo eran un camino hacia la apropiación de una identidad más blanca, distanciándose de su condición racializada para acceder al estatuto de «blanco». Incluso era posible comprar el documento denominado Gracias al sacar, que dispensaba a una persona de su calidad de "pardo», como lo evidencia la lista de aranceles, de 1801, que transcribe Ots Capdequí (11).

Como lo presenta Roth Deubel, durante el periodo republicano que tiene lugar después de la independencia, el ánimo del espíritu ilustrado llevó a promover los ideales de la igualdad abstracta entre los ciudadanos. Un impulso que, no obstante, se materializó en la legitimación de la dominación criolla, ya que, bajo el concepto de ciudadanía, se incluyó solamente a los varones, mayores de edad, que tuvieran propiedad o renta que no proviniera del trabajo como jornaleros y servidores domésticos (LaRosa y Mejía 72). Del mismo modo, la educación era de acceso exclusivo para españoles, criollos y miembros del clero, por lo que la admisión a cargos públicos o a oficios profesionalizados estaba negada a las comunidades negras o indígenas, conservando los privilegios en manos de quienes ya los tenían en el sistema colonial. En este periodo se consolida la idea de que Colombia es una nación mestiza, asociando este mestizaje a la igualdad que supera la diferencia racial. Sin embargo, la homogeneización mestiza se relacionaba con un mestizaje de corte criollo andino, silenciando la marginación que sufrían las comunidades negras e indígenas y ocultando los intentos del reconocimiento e inclusión de esta herencia dentro de la concepción identitaria colombiana. Aquí, ser negro, con todos los rasgos físicos y culturales que esto implica, es una categoría históricamente construida y asociada con una carga social negativa, lo que explica que el uso de este adjetivo implique aún ahora una agresión que genera resentimiento (Prescott, Without hatred... 32).

A principios del siglo XX, como lo presentan LaRosa y Mejía, Colombia era un país predominantemente rural. En los centros urbanos se promovía la profesionalización, lo que aumentó el sector de servicios y empleados y un crecimiento de la clase media. Pero este avance del sistema capitalista dejaba por fuera al grueso de la población, especialmente la afrodescendiente e indígena, aumentando la desigualdad instituida desde la Colonia. El impulso de la modernización industrial y urbana confluye con el impacto de la Gran Depresión y la guerra entre Colombia y Perú por las fronteras en el Amazonas, por lo que en los años 40 predomina 
en el país un ambiente de tensión política y económica que desembocaría, con la lucha bipartidista entre conservadores y liberales, en lo que se conoce como el periodo de "La Violencia», luego del asesinato del candidato presidencial Jorge Eliécer Gaitán en 1948 (6465).

En medio de una crisis política naciente en el país, llegan del Caribe las voces de una ola de apropiación positiva y reivindicativa de lo negro, que, en las figuras de Aimé Césaire o Nicolás Guillén, tendrán eco en la literatura afrocolombiana. Los intelectuales de la negritud y del negrismo configuran, como lo analiza María Elena Olivia, un movimiento literario y cultural de reconocimiento de una identidad negra colectiva históricamente excluida, cuyo lugar y cuya riqueza deben ser visibilizados y valorados, despojando a lo negro de su carga negativa y afirmándolo en contra de lo blanco y europeo. Las lecturas de estos autores y los diálogos que se establecen con ellos marcarán algunas de las producciones literarias de la época. Sin embargo, contrario a la postura de los autores isleños, el mundo hispano-suramericano asume "una negritud híbrida, menos eurofóbica y afrocéntrica (...) y más mestizada que la del caribeño" (Lawo-Sukam, Acercamiento... 41), por lo que los autores afrocolombianos no se aíslan de la cultura europea, sino que se asumen dentro de un proceso de integración étnica y cultural (42).

La producción de autores afrocolombianos en torno a este ánimo de reivindicación no entra de inmediato en los medios editoriales más importantes. En las publicaciones dominantes, como fue el Suplemento literario del periódico El Tiempo, entre cuyos responsables figura el poeta piedracielista Eduardo Carranza, se mantiene la línea centralista conservadora que defiende "la nunca fundamentada afirmación de una especie de colombianidad inmune a las disonancias de unas periferias cuya existencia no se reconocía sino en dosis homeopáticas" (Gilard 221). Tanto Martán Góngora como Artel producen sus poemarios en este contexto, el cual es animado, por una parte, por el negrismo y, por el otro lado, por una estética purista de línea española que era dominante en el canon andino desde el siglo XIX.

En Evangelios y en Tambores se evidencia el gesto identitario de una voz lírica que se autoafirma afrodescendiente, al mismo tiempo que recurre a un lenguaje poético hegemónico asociado a la estética de Piedra y cielo, un estilo cuyos límites son difusos, pues con esta categoría se agrupan obras de características heterogéneas que no responden a la unicidad de un movimiento, generación o grupo (Restrepo Restrepo 29). Los Cuadernos de Piedra y Cielo 
se publicaron entre 1939 y 1940, con siete entregas de poemas acompañados de una introducción que esbozaba una poética de ruptura frente a la tradición conceptual, moral o piadosa de finales del siglo XIX, en busca de un lirismo sublime y sentimental (Rodríguez Barranco 201). Los textos introductorios hechos por el poeta Jorge Rojas defendían una poesía pura cercana a la tradición española de la generación del 27, a través del poeta Juan Ramón Jiménez, cuyos versos dan título a la publicación. Destaca en esta poética la figura de un poeta vidente que quiere develar con su palabra una verdad metafísica, a través de un estilo lírico que a veces se torna recargado y abstracto (Restrepo Restrepo 35).

Maglia identifica en el estilo solemne e hímnico de Piedra y cielo una evocación de la retórica neoclásica consonante con una ideología republicana tardía (84-85), lo cual refuerza la idea de que el piedracielismo no implicó una verdadera ruptura, sino una continuación del culto al hispanismo y al catolicismo dominante en la poesía decimonónica (Restrepo Restrepo 40-41). Martán Góngora y Artel usan este lenguaje poético que excluye la disonancia periférica de la raza para fracturar el espacio de dominación andina y recuperar la herencia africana, en un gesto contencioso de autoafirmación y resistencia que se circunscribe al marco de la cultura letrada nacional.

\section{Mestizaje y paisaje en Evangelios del hombre y del paisaje}

La amplitud y diversidad de la obra del caucano Helcías Martán Góngora ofrece un rico escenario para el despliegue de la identidad afrocolombiana. Nacido en Guapi, en 1920, Martán Góngora venía de una familia acomodada de herencia francesa, española y payanesa, y tuvo una activa participación en la vida intelectual y política en diferentes departamentos del Pacífico. Empieza su producción poética con Mazorca de sueños (1939) y Evangelios del hombre y el paisaje (1944), que luego serán acompañados de una amplia producción literaria y ensayística, entre la que se encuentran una novela, más de 70 poemarios publicados e inéditos y múltiples colaboraciones en la prensa nacional. Además, fue editor de las revistas Vanguardia y Esparavel, miembro de la Academia de Historia de Popayán y de la Academia Hispanoamericana de Letras, y ocupó cargos públicos en la Alcaldía de Buenaventura y en la Asamblea Departamental del Cauca, entre otras responsabilidades y distinciones. Falleció en Cali en 1984.

Su condición mestiza lo lleva a describirse como mulato (Martán Bonilla 70), aunque Prescott (Voces... 25) considera necesario aclarar que era de piel más bien clara y de facciones 
menos negroides, como también lo hace Martán Bonilla (57). Se trata de un señalamiento que probablemente acota la extensión de la «negritud» del autor y que exigiría la consideración adicional que hacen ambos críticos cuando precisan que, a pesar de este hecho, se trata de un autor que sí explora la "experiencia afrocolombiana" (Martán Bonilla 57; Prescott, Evaluando... 555), lo que en opinión de Prescott salvaría a la obra de Martán Góngora del olvido, contrario a aquellos escritores afrodescendientes que ceden a la "engañosa universalidad" (556). Si para Prescott el hecho de centrarse en la identidad afro es condición para pasar el filtro de la crítica, Vanín, en contraste, considera que fue quizás la fidelidad al litoral Pacífico lo que alejó a Martán Góngora de cierta crítica, agregando que los elogios que obtuvo hablaban siempre de su lirismo refinado, pero no se refirieron nunca a sus "poemas negros" (20). La tensión entre el color de piel del autor, su interés por los personajes negros y su lenguaje poético de tradición europea ejemplifica cómo la pertenencia, autoafirmada o adscrita, a la categoría de lo afro es una cuestión dinámica que debe entenderse como una relación multidimensional y no como una condición esencial.

Las maneras en que la identidad afrodescendiente se pone en escena en los poemas de Martán Góngora varían y evolucionan. Martán Bonilla afirma que el primer libro centrado en el hombre negro es Humano litoral de 1954, pues es allí donde "el poema se centra en la simbiosis del hombre con sus ancestros y el paisaje nativo, para constituirse en un himno a la raza, al mundo rural" (61). Prescott (Voces) señala que la presencia negra es también nuclear en Mester de negrería (1969). Música de percusión (1973) y Breviario negro (1978). Por su parte, Lawo-Sukam (Nueva voz), al analizar la relación entre la identidad afro y el paisaje, destaca, además, Cauce (1953), Océano (1950) y Escrito en el Valle (1977). En estos análisis no se menciona el caso de Evangelios del hombre y el paisaje (1944), un libro de juventud cuyo núcleo es también la relación con el paisaje y la identidad racial, una exclusión que invita a abordar el poemario desde esta perspectiva.

En su presentación a la segunda edición de Evangelios en el 2010, al ser incluido en la Biblioteca de Literatura afrocolombiana del Ministerio de Cultura, Vanín señala que este texto se articula a partir de "las contradicciones entre el canon estético europeo y su relación con el mundo negro" (24), producto de una "fijación por Europa" por parte del autor (25); contradicciones que serán superadas en libros posteriores cuando Martán Góngora se sitúe en el mismo plano de "sus iguales étnicos a los que miraba desde cierta distancia en sus inicios" 
(25). Esta descripción parece extender el proceso identitario del autor al texto poético, homologando el proceso de reconocimiento del poeta como miembro de la comunidad afro con un distanciamiento progresivo de los tópicos y estilos de la lírica europea y, especialmente, de la lírica castellana del Siglo de Oro. La premisa tras esta consideración es que si la poesía, en su lenguaje o personajes evocados, apela al canon estético heredado de España, se aleja necesariamente de las cuestiones propias de las comunidades negras. Tal idea mantendría la dicotomía Europa-África a la que se refiere Valero (33), la cual opone las estéticas blancas a las estéticas negras y, con esto, simplifica los deslizamientos y negociaciones que ocurren en el texto literario.

Evangelios del hombre y del paisaje es un libro compuesto de poemas en prosa cortos e identificados únicamente por un número, organizados en cinco partes: "Evangelio del paisaje», con 20 poemas; "Evangelio del amor», con nueve poemas; "Pausa: parábola de la soledad», con ocho poemas; "Evangelio de la doncella", con 17 poemas subdivididos en dos partes; y «Evangelio del hombre», con ocho poemas. Las partes conservan una voz poética y un estilo homogéneo; el yo lírico habla en primera persona, evidenciando una confianza profunda en los alcances de su enunciación y preocupándose por describir su situación emocional y su entorno con la potencia de sus recursos retóricos. Afirma, con certeza: "Yo digo el mar. Lo digo como hombre que su amor canta con verdad profunda" (37); "Yo pude con mis besos modelar como Dios formas humanas" (116); "Doncella: yo te creé, en el sueño" (89), "Para que tú sonrías me visto de bondad. Y melifico siempre" (94).

La confianza del yo lírico en la capacidad enunciativa de su voz hace que la prosa lírica de los textos esté llena de tropos, como símiles: "Y tu nombre perfecto como los pétalos de un jazmín" (63); hipérboles: "Desde su almena divisaría el porvenir, detendría las nubes e inventaría colores al crepúsculo" (105); prosopopeyas: "El viento alzaba sus vestidos de holanes" (64); epítetos: "(...) los ojos del hombre solitario agonizaron en la postrera página" (84); y múltiples metáforas: "Para formar tu corazón, yo tuve entre mis manos el corazón inmenso de mi madre" (89). Este lenguaje se relaciona con el piedracielismo que Vanín sitúa en la obra de Martán Góngora (15) y que conecta con la poesía pura de la generación del 27, la cual está animada por una búsqueda de la esencia del lenguaje de la poesía (Rozas 228), un esteticismo que resuena con el último verso del libro: "X. Codiciad la Belleza, eternamente la Belleza" (119). 
Evangelios construye un tejido simbólico e intertextual que pone en contacto este lenguaje poético de principios del siglo XX con referentes bíblicos, renacentistas y barrocos, lo que se evidencia en las evocaciones de Babilonia (104), Las mil y una noches (44) o el pintor del Quattrocento, Fra' Filippo Lippi (99). Este interés intertextual se hace más evidente en «Evangelio del amor», el cual recupera el Cantar de los cantares y despliega un diálogo entre la voz poética y la voz de la Amada, una doncella rubia (63) guardada por doncellas negras (67), y ubicada en un contexto marítimo anónimo rodeado de palmeras (68). A este paraje llega el yo poético guiado por un Ángel después de una larga travesía (73) y allí planea construir "tiendas nómades" con blancas lonas junto con su Amada (66). La figura del Señor, que se presenta en simultáneo con la figura del Profeta, sigue el intertexto bíblico y personifica al creador (65). La experiencia amorosa, por su parte, se describe con imágenes barrocas de corte místico, como la flecha divina que hiere el corazón, cercana al éxtasis que describe la poeta del Siglo de Oro Santa Teresa de Jesús (89), o el matrimonio espiritual (69) que ocurre al lado del mar y que es homólogo al encuentro de los amantes en el Cantar de los cantares.

«Evangelio del amor» conecta con "Evangelio de la doncella», el cual conserva el tono evocativo de un encuentro amoroso, pero sin la forma dialogada. La voz poética canta "un evangelio de alabanza" a una doncella rubia (89) de ojos azules (95), cuya hermosura es una "gracia de Dios" (91). El yo poético afirma que haberla encontrado es motor de su "música del verso" (92), con la cual él melifica el "evangelio del amor" (94), usando sus versos como salmos (102). El sujeto poético se presenta como un navegante que llega a su Doncella, a quien describe como una isla en medio del mar (94); ella, con la guía de sus ojos, le impide naufragar (95) y lo lleva a tierra firme para estar juntos, dejando en él la nostalgia del mar (100). Estos poemas ejemplifican la recurrencia de la temática marina en la poesía de Martán Góngora, como lo señalan varios de sus críticos (Martán Bonilla 57; Prescott, Voces... 26; Vanín 23).

"Evangelio de la doncella», "Evangelio del amor» y los textos que los separan, agrupados bajo el nombre de «Pausa: Parábola de la soledad», y que componen una alegoría de un proceso espiritual, no abordan de manera directa el cuestionamiento de la identidad racial afrodescendiente. Volviendo al prólogo de la edición del 2010, que reduce la cuestión identitaria a la dicotomía negro-blanco o África-Europa, Evangelios se ubicaría del costado blanco europeo, y sería por esto una obra previa al acercamiento del autor a sus "pares étnicos" (Vanín 25). Lo 
que parece proponer esta afirmación del prólogo es que Evangelios no incluye una poesía lo "suficientemente" negra y, quizás por esta razón, no ha sido incluido en los corpus de análisis de temática afro que se han hecho sobre la obra del autor. En esta falsa lógica de exclusión mutua, la predilección por la lírica europea y la presencia de blancas doncellas, rubias y de ojos azules, neutralizarían la cuestión afro, por lo que sería necesario que el poeta se desvincule de su «blancura», para lograr, en poemarios posteriores, concentrarse en la faceta negra.

Tal simplificación del proceso identitario de la raza impide apreciar los modos en que lo afro se presenta en Evangelios y los recursos que allí se despliegan para configurar la pertenencia a una comunidad cultural. La pregunta por la ascendencia, estrechamente vinculada con el problema de la identidad racial y étnica, es central desde el epígrafe ("En el nombre de Ana, del paisaje y de mi sangre") y es el centro del último bloque de textos, titulado "Evangelio del hombre». Aquí la voz poética afirma estar buscando su sangre (111), un llamado que se dirige a la recuperación del origen y que apela directamente a la raíz de la madre ("Y cuando yo te nombro [madre], eterna ola, tu sangre me golpea el corazón" [112]). La sangre, como presentan Chevalier y Gheerbrant, tiene una carga simbólica asociada al principio de una generación y al vehículo del alma, de donde viene su importancia en los ritos sacrificiales (909910). En «Evangelio del hombre», la búsqueda de la sangre es asumida por un sujeto lírico unitario que quiere cantar este origen, de manera que, cuando llegue la muerte, su sangre pueda seguir fluyendo y él alcance una forma de inmortalidad, reservada a la divinidad. El yo lírico afirma: "Todos teníamos un nombre y un corazón que nos decía: Busca tu sangre, para que cuando calles, su marea cordial cante en la vida" (111). Y luego: "La muerte ronda ya por mis dominios. Nadie dirá que en vano ha de truncarme, porque mi sangre seguirá fluyendo... Nadie podrá decirlo. Y hasta Dios maldecirá, colérico, mi sangre" (116).

El llamado a buscar su origen, su sangre, aparece desde la infancia del sujeto poético ("Busca tu sangre, me dijo el corazón en la infancia. En la cuna, apenas entendía esa voz" [114]); una misión que ya había sido adelantada por sus hermanos ("Yo sabía que [sobre] esta cosecha (...) pesaba mi dominio incompleto [115]). Pero la voz lírica señala que hacía falta salir en un éxodo (115) para encontrar su propia sangre. Y lo que encuentra al final de este viaje, como se presenta en el poema número 7, es un origen ancestral, una sangre multiétnica de arraigo mundial y transhistórico, lo que borraría toda frontera geográfica o temporal: 
Bendita sea la sangre que corre desde el principio de los hombres por las venas del mundo: sangre antigua de Adán, virgen sangre de Eva. (...) Bendita sea la sangre de Francia, la de Italia y de Goethe, y la sangre de Asia, de Oceanía y de África. Bendita sea la sangre de España y de Cristóbal Colón. Y la sangre de Europa, en la guerra y la paz (117).

Este origen múltiple es el centro articulador de la primera parte del libro, "Evangelio del paisaje», donde se escenifica una identidad racial plural que la naturaleza costera acoge armónicamente. El paisaje asume aquí un rol central en la articulación de la voz poética mestiza; esto se evidencia en el primer poema que, siguiendo el modelo del libro bíblico del "Génesis», dice: "En el principio fue el paisaje, verde y azul, como la tierra niña y como el mar infante. (...) Después, vinieron gentes de África y de España. Y la música se hizo labio y habitó en nuestra alma mulata y melodiosa, como si fuera un cascabel de júbilos, modelado en arcilla por las manos de un cholo" (35). El Dios creador es aquí un "cholo», voz de origen quechua que, como recoge el diccionario electrónico de la Real Academia Española de la lengua (s. f.), designa a una persona mestiza o una persona indígena que ha asumido costumbres occidentales. La condición mestiza del creador precede a la llegada de las "gentes de África y de España», por lo que se trataría de un mestizaje originario y ancestral arraigado en la tierra, así como en la sangre que late profunda en la voz lírica de «Evangelio del hombre».

El sujeto poético de «Evangelio del paisaje» canta a este paisaje mestizo, el cual describe como una naturaleza voraz y homicida (36), pero también de ríos cristalinos donde se bañan las doncellas (39) y que es hogar de aldeas llenas de sonrisas (44). La naturaleza en estos poemas supera el tópico del locus amoenus que propone un país de ensueño, la Arcadia de Virgilio, siempre tranquila e inútil (Curtius 273). Aquí el canto a la naturaleza desborda también las relaciones que propone Lawo-Sukam para otros poemarios del autor, esto es, el tono nostálgico del paraíso perdido, la angustia ante la destrucción de sus recursos o el sosiego que brinda ante las tensiones de la ciudad (Nueva voz). En «Evangelio del paisaje», el litoral constituye el hogar de la identidad mestiza donde habita la voz poética; estos son poemas láricos, usando la categoría del escritor chileno Jorge Teillier, pues abren un espacio donde el poeta "no se siente solo, sino siempre rodeado de un mundo físico al cual pertenece y que le pertenece, y de antepasados que lo acompañan en su tránsito terrestre" (ctd. en Binns 57). El lar latino es homologable al oikos griego, ambas voces traducidas al español como hogar, y es 
una instancia que ofrece el arraigo profundo donde confluyen lo individual y universal, configurando el espacio singular del poema (Binns 45)

Este paisaje del litoral es una naturaleza costera anclada a un territorio, el del Pacífico. Así lo demuestran los topónimos utilizados para nombrar los ríos (40), como el río Guapi o Micay, la geografía del Cauca (50) o el océano Pacífico colombiano (59). Este paisaje costero ofrece el don de la celebración, como lo llama Forns-Broggi, pues permite "la proyección transversal del sujeto poético que entra en un espacio ritual, donde no hay división entre naturaleza y cultura" (214). Enmarcada en el ambiente de la costa, la voz del poema asume una dimensión colectiva que otorga al paisaje un carácter épico y mítico, lo que le permite cantarle y cantarlo en el festejo de su diversidad racial armónica. Al mismo tiempo, este paisaje lárico ofrece el don del reparo (Forns-Broggi 212), toda vez que permite a la voz del poema recuperar los ecos ancestrales perdidos, creando un paraíso verbal como espacio simbólico de acogida a la diversidad étnica y racial. De allí que este hogar mestizo cobije a los "atletas griegos" (36) y a la rumba de "caderas maceradas de ébano" (36), y que al lado del mar convivan los hombres mediterráneos y litorales (37), las muchachas injerto de dos razas (45), las doncellas de Las mil y una noches (44) y las cogedoras de arroz (49), todos en medio de cantos africanos de celebración $(52,59)$.

La convocación de personajes, objetos y referentes de diversas tradiciones, razas y clases sociales es transversal en «Evangelio del paisaje». Por ejemplo, en el fragmento 17 se usa el vocativo en vosotros, de tradición castellana, como llamado a celebrar al artesano que construyó el cununo y el guasá (instrumentos musicales del Pacífico), quien también hizo el tamboril, de la península Ibérica, y el bombo, también europeo; así como la marimba, que es "mulata y africana" (54). Del mismo modo, en el fragmento 5 se canta al río Timbiquí, que se caracteriza como "africano, francés, cosmopolita" (40). En el fragmento 19, por su parte, se canta al guarapo, voz quechua que designa una bebida fermentada, y que es calificado como mulato al guardar en su linaje múltiples tradiciones: "Guarapo, hijo natural de la familia del coñac, del brandy, de la champaña, del whisky, de la cerveza y del aguardiente; guarapo mulato como la miel y como el ron, hermano mío" (58). Aquí, el sujeto poético se sitúa en conexión fraterna con el guarapo, pues este también tiene una sangre ancestral sin fronteras temporales ni geográficas. 
De este modo, el sujeto poético de Evangelios construye una identidad racial y étnica múltiple, animada por raíces ancestrales europeas, africanas y americanas. Estas facetas de su identidad logran convivir armónicamente en el paisaje del litoral Pacífico, donde Dios habita el vaivén de las palmeras (46). Pero este don del reparo, de la celebración y la convivencia no oculta la disputa de la identidad, su carácter contencioso. El reconocimiento mestizo funciona como un proceso performativo de la identidad, porque se ubica en una zona de conflicto, lo que se hace evidente en el poema que cierra "Evangelio del paisaje». Allí, el yo lírico sostiene: "Cuando Colombia agregue a su mapa melódico las islas y las radas del océano Pacífico, el bambuco, el pasillo y el porro tendrán la compañía fraternalísima de estos afluentes del currulao, que es el Amazonas de los bailes, dueño y señor de los holgorios sabatinos y navideños en las costas del Sur" (59). El paisaje lárico del Pacífico es lugar de arraigo mestizo; pero no así el territorio colombiano. Y la advertencia de la voz poética es que solo cuando los componentes negro e indígena se unan a la tradición andina, será posible extender la celebración y el gozo fraterno a toda la nación.

Entonces, ante el reconocimiento de una ruptura en el sentido de pertenencia nacional, la voz lírica se afirma en su mestizaje ancestral como reparo de esta separación entre los orígenes españoles, africanos y americanos, y ofrece el paisaje del litoral Pacífico como morada espiritual de la celebración y la convivencia de la diversidad. Quizás es esta su «buena nueva», su «evangelio»; la posibilidad de escenificar una identidad múltiple cuyas contradicciones danzan rítmicamente al son del currulao, una melodía que recoge la voz de un pueblo de "reyes de la selva" que fueron esclavizados y que ahora cantan en el Pacífico (59). El llamado de este evangelista a sus "amigos" $(54,59)$, a sus "hermanos" (41), es a unirse a la fiesta de la danza y el paisaje.

De este modo, Evangelios se compone como la búsqueda de la identidad de un yo lírico que, en su éxodo para encontrarla, halla ecos universales y atemporales que son convocados en sus versos. El lenguaje poético, rico en recursos, se usa para cantar a las doncellas rubias y a las caderas de ébano, al Dios cholo del Pacífico y al Profeta de tiempos bíblicos. El litoral del Pacífico funciona como un entorno lárico que permite la celebración de esta identidad plural y la recuperación de sus ecos múltiples, un paisaje que se concibe mestizo en su origen y que, por lo tanto, puede acoger el canto de un yo lírico que se reconoce él mismo mulato, como el guarapo. La identidad afrodescendiente que se despliega en «Evangelio del paisaje» y «Evangelio 
del hombre» no se concibe en oposición a las raíces europeas, sino como un río de sangre que integra muchos cauces. Este gesto identitario autoafirmativo permite al yo lírico evidenciar que el mestizaje originario no ha sido incorporado a la identidad nacional, por lo que la puesta en escena de su identidad racial es detonante de un llamado de alcances políticos para relievar una tensión aún en disputa entre lo andino y lo costeño en Colombia.

Evangelios del hombre y del paisaje de Helcías Martán Góngora ofrece, en efecto, una puerta de acceso a los modos en que el problema de la raza y del origen africano en Colombia son puestos en escena. Solo que esta performance desborda las relaciones naturalizadas y dicotómicas de la oposición entre Europa-África y, en su lugar, teje una identidad integradora que encuentra su arraigo singular en el paisaje.

\section{Ancestralidad musical en Tambores en la noche}

Agapito de Arcos, conocido con el nombre artístico de Jorge Artel, nace en Cartagena en 1909 y muere en Malambo (Atlántico) en 1994. Se graduó como abogado de la Universidad de Cartagena en 1945, aunque no ejerció la profesión y se dedicó al periodismo y a la literatura. Publicó las colecciones de poesía Tambores en la noche (1940), Poemas con bota y bandera (1972), Sinú, riberas de asombro jubiloso (1972), Coctel de estampas (1972) y Antología poética (1979). Además de sus libros de poemas, Artel tiene una novela titulada No es la muerte, es el morir (1979) y una obra teatral llamada De rigurosa etiqueta, por la cual recibió varios premios y honores.

La obra de Jorge Artel ha sido muy visitada por la crítica, pues se le considera uno de los principales representantes de la poesía de temática negra, o poesía negra, que tuvo su auge entre 1930 y 1940 (Maglia 83). En sus poemas se despliega el legado cultural del pueblo caribeño, exaltando la herencia racial y étnica afro como un elemento vivo de la identidad colombiana, una herencia que se manifiesta en diversas expresiones como la lengua, las danzas, los cantos y las prácticas religiosas. El despliegue de lo que Jackson llama "identidad africana", "identidad colectiva africana" o "autenticidad africana" (ctd. en Valero 23) en la obra de Jorge Artel puede abordarse desde el ejercicio de preservación de la memoria de las comunidades afro, frente a la que el cartagenero hace "una defensa poética de la resistencia cultural negra" (Mahop Ma Mahop 17), poniéndola en diálogo con las supervivencias españolas e indígenas. 
En el caso de Tambores en la noche, los 43 poemas escenifican el diálogo espiritual con los ancestros, donde los elementos sustanciales de la cultura africana e indígena revelan el proceso de mestizaje. En estos textos, el yo lírico reafirma el vínculo con su ascendencia afro y trata temáticas relacionadas con las negritudes, desde la dimensión geográfica (el paisaje y el mar), sociopolítica (la esclavización del pasado y la desigualdad del presente) y cultural (la música, la danza y la tradición oral). Allí, la negritud funciona como "una contextualización de los fenómenos socio-históricos y culturales de la hibridez y no [como] una mera africanización de la cultura" (Lawo-Sukam 42).

La defensa poética de la herencia afro que se lleva a cabo en el texto de Artel combina procedimientos poéticos de herencia europea y rasgos dialectales de la oralidad del afrocaribeño, por lo que allí conviven el lenguaje solemne de corte piedracielista con las voces populares de la cotidianidad. Maglia califica este gesto como una "resistencia letrada», pues busca legitimar la oralidad propia de una etnia utilizando la máscara de la herencia hispánica (83-84). Este «enmascaramiento» obedece a un espíritu de época, como la autora señala, pero también puede identificarse allí una voluntad de hacer visible la identidad negra periférica en los marcos hegemónicos andinos, como lo evidencia el título del poema «Soneto más negro» (97). Lo contencioso del reconocimiento afirmativo de la herencia afro ocurre al ponerse en un contexto histórico de exclusión y desconocimiento de estos elementos culturales negros; se trataría de una performance identitaria que busca integrar la diferencia al exaltarla y darle valor.

El poemario propone un diálogo con el ancestro por medio del canto, la danza y los rituales, creando un nexo entre marimbas, tambores de madera y cuero y sonajeros de semillas, que hace de la música una entrada al universo cultural mestizo. Indígenas y africanos fueron sometidos a la servidumbre y este "encuentro forzado» posibilitó de manera trágica el intercambio cultural de estos grupos, como presenta Valderrama a propósito de la obra de Delia Zapata Olivella (281). En Tambores en la noche, el mestizaje producto de la unión entre el tambor africano y la gaita indígena permite al yo lírico un viaje a través de las generaciones pasadas y presentes para encontrar al ancestro vivo que resuena en estos sonidos, haciendo de la música un transporte de los saberes e historias de aquellos que resistieron y sobrevivieron a la colonización, a la represión y al sometimiento de la población esclavizada. La inclusión de la música y la danza popular mestiza dentro del discurso lírico implica "una conexión entre el yo de la enunciación, el mundo ancestral de la memoria y la cotidianidad del presente" 
(Cabarcas 76), configurando en el poema un espacio para convocar el pasado desde una mirada constructiva e interpretativa de la historia.

Tambores en la noche pone en contacto la identidad afrocolombiana con la memoria ancestral y la dimensión espiritual en la música y la tradición oral como transporte de esta memoria. Como lo plantea Jaramillo, "la tradición oral y los cantos religiosos han sido un vehículo de resistencia para las comunidades afro-colombianas en su largo periplo americano" (Los alabaos... 294). Esta manifestación cultural se expresa en versos, dichos, refranes, coplas y adivinanzas, convirtiéndose en un mensaje transmitido de voz a oído en el mismo grupo étnico (Vansina 3), resignificando esa alegría estoica que es símbolo de la diáspora africana de territorios nacionales e internacionales. En este sentido, las imágenes sonoras ancestrales del poemario son refugio espiritual de esta memoria, albergada en los ritmos del currulao, el berejú, el agubajo, el bunde o el patadoré. También, en los cantos populares que resaltan la voz propia del negro que expresa su identidad racial, como el agualarga, la margarita, el gallinazo, el andarete, la tiguranda, el gigualo, la caderona o el anderele. La mayoría de estos ritmos autóctonos van siempre acompañados de bailes, voces y sonidos interpretados por instrumentos musicales que evocan y salvaguardan la memoria de la cultura africana.

La tradición oral de la población afrocolombiana se arraiga en la transmisión de elementos propios de una cultura africana que fue esclavizada y que, incorporando creencias occidentales y prácticas indígenas, mantiene viva la memoria al ritmo de los cantos. La melodía y el ritmo funcionan como un medio mnemotécnico que cumple una función similar a los objetos rituales utilizados por diferentes comunidades para recordar historias narradas de generación en generación. "Entre los medios mnemotécnicos que no hacen uso de objetos materiales, deben ser señalados los cantos y los ritmos de tambor. En todas las tradiciones cantadas hay un soporte mnemotécnico en la melodía o ritmo del canto. En todas partes de África, se encuentran los ritmos de tambor como medios mnemotécnicos" (Vansina 52). Este vínculo entre el ritmo y la memoria se hace evidente en el poema "La cumbia», donde el yo lírico presenta un festejo en medio de los "llantos de gaitas" y los "golpes de tambor". Al son de estos instrumentos danzan mujeres y marineros "como sierpes", "con pies furiosos" y "muslos epilépticos". Esta escena llena de imágenes sensoriales ("la axila cálida", "las caderas ágiles", "los gritos ebrios") desborda el placer sensual del baile y el éxtasis de la fiesta, en la medida en que la cumbia se convierte en un escenario identitario al unir a toda una "raza [que] grita". El golpe del tambor 
convoca la fraternidad, pues él "trae de los tiempos muertos / un coro de voces vivas"; su ritmo hace un llamado al origen y se convierte en un ejercicio de memoria. En él "late un recuerdo aborigen" de "abuelos (...) que eran negros", por lo que la cumbia que nace de este tambor la declara el yo lírico como "danza negra, danza de mi tierra" (54-55).

La conexión espiritual con el ancestro articula la identidad mestiza afrodescendiente del yo lírico, la cual es autoafirmada a lo largo del poemario. En «Mi canción», el sujeto poético describe su canto como una "estrofa negra, borracha de gaitas vagabundas / y golpes dementes del tambor" y afirma que fue el paisaje de la costa quien le dio "la canción", relacionando el componente étnico ancestral con el paisaje costero. La enunciación se realiza desde la confianza en la capacidad de elevar su voz, con la rebeldía enseñada por el mar, su "hermano mayor", por lo que la voz poética puede convocar a las "palmeras cimbreantes", a las "olas despeinadas" y compartir su canción con "marinos ebrios" y pescadores que la creen suya, dado que sus versos se combinan con este paisaje que describe, se yergue en los mástiles y se esconde en las redes (84-85). Este poema, como "La cumbia», se convierte en un lugar fraterno de encuentro de una raza, el cual es creado por el lenguaje y donde se reúnen quienes comparten la herencia que allí resuena y que hacen suya.

La dimensión espiritual de la memoria se vuelve eje de la defensa identitaria en Tambores en la noche y conecta con una serie de prácticas religiosas de herencia africana, que en su momento sirvieron de refugio para las personas esclavizadas, configurando "armas simbólicas" de resistencia (Jaramillo, Los alabaos... 227). Las comunidades esclavizadas guardaban un profundo respeto por sus conocimientos y raíces espirituales, que los llevaban a soportar las duras y extremas condiciones tanto corporales como mentales. Los colonizadores rechazaron estas prácticas y la Iglesia tuvo un papel activo en la evangelización de estos grupos, lo que trajo como resultado la convivencia de prácticas y el sincretismo de representaciones religiosas occidentales y africanas. La conservación de sus cultos a través de la utilización de nombres católicos para deidades africanas o la incorporación de ritos africanos en ceremonias católicas es, según Cifuentes, un refugio espiritual que sirve de aliciente e inspiración (17). Lawo-Sukam ve este sincretismo como resultante de una "técnica de camuflaje" (Acercamientos... 47), ya que, al mezclar las prácticas, el subalterno simula aceptar los ritos del orden dominante sin perder su propio sistema cultural. 
El sincretismo religioso se une a las expresiones musicales en manifestaciones como los arrullos, los alabaos o los chigualos, predominantes en el Pacífico. Siguiendo a Cifuentes, los arrullos son cantos de festejo para los santos o el niño Dios; se usan también en los chigualos o velorios de niños menores de un año, llamados «angelitos» o «gualís» (66-69). El alabao, por su parte, es un canto fúnebre para adultos, que no tiene acompañamiento instrumental. Estos ritos religiosos de herencia afro se observan en el poema «Velorio del boga adolescente», donde se despide con regocijo, amor y reconocimiento a un joven, celebrando lo que fue en vida. La voz poética describe el velorio: "Desde esta noche a las siete / están prendidas las espermas: cuatro estrellas temblorosas / que alumbran su sonrisa muerta", precisando cómo el cadáver reposa limpio, vestido con "la franela / y el pañuelo de cuatro pintas / que llevaba los días de fiesta". Este velorio lo compara con una celebración "Ilen[a] de tambores y de décimas", quizás aludiendo a los cantos fúnebres de herencia africana; los alabaos "¡hacen pensar en los sábados / trémulos de ron y de juerga, en que tiraba su grito /como una atarraya abierta!" (59-60). Jaramillo señala cómo estos ritos de conmemoración de la vida y la muerte permiten convocar "ese yo verdadero que ha sido silenciado" (Los alabaos... 294), en la medida en que recrean la espiritualidad ancestral y ponen en escena la recuperación activa y constructiva de la memoria vinculada a la identidad afrodescendiente.

El sincretismo religioso se evidencia también en "Los chimichimitos", poema que tiene como intertexto una ronda infantil de la tradición oral de Venezuela. "Los chimichimitos (...) son seres diminutos que habitan en cuevas y se alimentan de huevos de guácharos" y que la leyenda ubica como producto de "las almas de los niños y niñas que mueren sin bautismo" (Ruíz s. p.). El proceso de evangelización llevado a cabo con las comunidades africanas utilizó este tipo de recursos al miedo para ejercer presión, generando amenazas frente a lo que puede pasar en la vida después de la muerte si no se seguían los ritos católicos. En el caso de la ronda infantil, los elementos religiosos se mezclan con los ritmos del tambor y con el baile propios de la cultura afro y esto se evidencia en el poema: "Los chimichimitos / dejaron sus grutas / tejiendo el hechizo / del chimichimal... // Negrito de Venezuela, / ¿no te vas a bautizar? / ¡Ve que si no te bautizas / los chimichimitos te van a llevar! / "Los chimichimitos / estaban bailando / el coro corito ¡Tamboré...!!”" (92).

La recuperación de la tradición oral conserva contenidos sociales y dimensiones lingüísticas (Montemayor 55); este segundo aspecto podría señalarse en Tambores en la noche 
en la transcripción del dialecto costero caribeño que se lleva a cabo en poemas como «El líder negro", donde se hace referencia al líder chocoano Diego Luis Córdoba (Maglia 85) al decir: “¡El pueblo te quiere a ti, / Diego Luí, / el pueblo te quiere a ti! // Con too y que ere bien negro / ya lo blanco te respetan / porque dices la verdá, / y se quitan el sombrero / cuando te miran pasá" (68). No se trata, como explica Mendizábal, del exotismo del escribiente blanco que quiere mostrar el "habla negra", sino de la "apropiación de la lengua dominante por parte del sujeto subalterno" (95). La defensa poética identitaria que lleva a cabo Artel se inscribe en el ejercicio de posicionamiento de "lo negro en el panorama blanco-mestizo", como ya lo había hecho el momposino Candelario Obeso en sus Cantos populares de mi tierra publicado en 1877. La sonoridad del habla afrocaribeña, resultado de "la asimilación forzada de la lengua (...) por quienes sufrieron los procesos de esclavización" (Mendizábal 94), se fusiona con la música y la danza en «Bullerengue», configurando un mismo gesto performativo de resistencia cultural: "Quisiera vorverme gaita / y soná na má que pa ti. / Pa ti solita, pa ti, pa ti, / mi negra, pa ti. // Y si fuera tamborito / currucutearía bajito, / bajito, pero bien bajito, / pa que bailaras pa mí" (67).

La relación triádica entre el habla, la memoria y el conocimiento ancestral tejen "un rico y complejo legado cultural del origen africano (...) [que] aflora en diversos aspectos de la vida cotidiana" (Jaramillo, Mary Grueso... 217). La memoria ancestral se consolida en creencias, ritos y danzas, incluyendo facetas artísticas, sociales, políticas y lingüísticas fundamentales en la cultura afrocolombiana, lo que muestra la consolidación de la herencia cultural africana en los territorios latinoamericanos, como lo refiere Wabgou (108). Los elementos constitutivos de la cultura afrodescendiente hacen parte del pensamiento creativo y literario construido a partir de las experiencias de los individuos de una comunidad, quienes, como seres sociales, aportan a un imaginario colectivo que fundamenta su identidad. De allí el llamado que se hizo en el 2001 en la Conferencia mundial contra el racismo respecto de la necesidad de reconocer y conservar este patrimonio cultural.

La memoria ancestral se ancla en la representación cultural de los antepasados africanos que en sus costumbres dejaron su legado. Volver a estos lugares de la memoria, espacios simbólicos configurados por la voz, el canto y el baile, implica, entonces, una puesta en escena de la identidad afro. Un proceso que se activa con el lenguaje en el poema y que permite al yo lírico construir una suerte de destino común para el pueblo afrodescendiente al articular la 
experiencia cotidiana con la tradición cultural. Como plantea Jaramillo, "es el desgarramiento y la censura que esos lugares evocan los que unifican a los descendientes de esclavos de diversas regiones de África y los Ilevan a tejer un origen y herencia" (Mary Grueso... 219). Recuperar la música y la tradición oral, como lo hace Artel en Tambores en la noche al visibilizar y celebrar la herencia africana ante la hegemonía andina de principios de siglo, es un acto performativo que impulsa una especie de regreso mítico a los orígenes (Lawo-Sukam, Acercamientos... 47). Este gesto es explícito en "Mapa de África», donde el yo lírico evoca su origen lejano: "¡Costa de los esclavos / -tal vez mi tierra- / perdida en los submundos hiperbólicos del sueño". África es irrecuperable para él, posicionado en el presente del poema, de manera que la mediación cartográfica lo lleva en un viaje imposible por parajes desconocidos, entre tardes de "radiantes policromías", las "Montañas de la Luna" y "la cordillera del Atlas". La riqueza ancestral de África, de "Songoi, Hamasá, Fulki y Bambara", ha sido opacada por la violencia y la explotación del continente, sometido por "un rótulo brutal: "colonia»". El yo lírico anuncia, o desea, el regreso y liberación de estas tierras, para que puedan resurgir "sus castillos de marfil", "sobre diamantes y esmeraldas"; pero se trata de un futuro incierto que no deja de ser una pregunta: "¿Cuándo podrán saltar estos colores, / tirar las letras -sus amarras- / que los clasifican como posesiones / y tomar su color, el único, / el verdadero color de África?" (122-123).

Así, la música y la tradición oral afrodescendiente tienden sus raíces hacia el pasado y, al ser transmitidas a través de las generaciones, no se limitan a relatar diferentes sucesos de la historia, sino que muestran el lado espiritual que conecta a la comunidad con la memoria ancestral a través de los cantos acompañados de instrumentos que evidencian el mestizaje. En este sentido, en la poesía de Tambores en la noche, como lo refiere Sandoval, "la música tradicional (...) posee una conciencia étnica y estética, incluso social, que retoma la literatura" (206). Recurrir a la música como lugar de memoria ancestral es un gesto que desborda el interés en la cultura popular o el folclor y se convierte en una afirmación identitaria, ya que el fenómeno musical opera un proceso de "patrimonialización y reconocimiento constitucional de la diversidad étnica y cultural" (Estupiñán 103). En el contexto de principios de siglo, el poemario propone una presentación del legado cultural afro en conexión con la memoria y el ancestro, configurando una comunidad unida por un origen, una historia y una cultura.

El poemario de Artel, muy anterior a las discusiones contemporáneas sobre la afrocolombianidad, pone ya en escena factores vinculantes de las comunidades negras, como 
la trata y el patrimonio cultural de la música y la tradición oral. La relación con este origen se da de manera espiritual como evocación de un pasado perdido, pero que late constante en la vida cotidiana. Al afirmar, en el primer poema del libro, "Negro soy desde hace muchos siglos. / Poeta de mi raza, heredé su dolor" (97), el yo poético se posiciona frente a su condición afrodescendiente y conecta su voz lírica con la puesta en escena de una raza, dando a su ejercicio identitario un impulso colectivo y fraternal.

\section{Conclusión}

Evangelios del hombre y del paisaje de Helcías Martán Góngora y Tambores en la noche de Jorge Artel son muestra del interés en la temática negra, a nivel latinoamericano, en la primera mitad del siglo XX. Estos autores, hombres mestizos afrodescendientes del Pacífico y el Caribe colombianos, respectivamente, llevan a cabo un ejercicio de afirmación identitaria en sus poemarios, vinculando la herencia africana como eje de este acto de reconocimiento. Ahora bien, todo ejercicio de identidad es un acto político performativo y contencioso que se pone en escena de diferentes modos y con diferentes recursos, como se observa en cada poemario.

Para el caso de Evangelios, el origen convocado es atemporal y universal, de manera que el componente afro convive, principalmente, con la herencia europea y, en menor medida, con la indígena. El pasado se asume como un río de múltiples cauces que se visibilizan en los poemas con los recursos poéticos de herencia hispana y los intertextos bíblicos, mediorientales y castellanos. En este texto, el paisaje del litoral es un lugar sagrado, un hogar que acoge la identidad plural y permite la convivencia armónica de los habitantes; esto es posible porque esta costa americana es en sí misma mestiza, al haber sido creada por un «Dios cholo». De este modo, el ejercicio identitario de Evangelios se da como celebración lárica de esta diversidad étnica y racial, en la que lo afro mantiene una relación horizontal con lo europeo.

En Tambores en la noche, en cambio, el origen mestizo convocado es predominantemente africano. El pasado se ubica en el continente negro y el vínculo con el presente del yo poético se establece a través de la historia de la esclavización de sus antepasados. El legado afro es una unidad cultural perdida en el tiempo, pero latente en diferentes expresiones cotidianas que son convocadas en los poemas. La recuperación de la música, la danza y las prácticas religiosas como lugares simbólicos de memoria pretende visibilizar y valorar la herencia africana estableciendo una conexión espiritual con el ancestro. El 
lenguaje poético de Tambores en la noche revela también su herencia hispana y sirve de mediación para poner en formas dominantes las realidades de una comunidad invisibilizada.

En ambos poemarios se presenta una voz lírica en primera persona, que hace uso de múltiples recursos retóricos de herencia europea para elevar sus cantos. Ambos sujetos poéticos configuran una instancia enunciativa unitaria y potente, que encuentra en el lenguaje la posibilidad de convocar sus orígenes y desplegar su performance identitaria. Esta voz poética asume, en ambos textos, una dimensión colectiva y fraternal que convoca a sus pares mestizos y los hace partícipes del ejercicio afirmativo de su condición de afrodescendientes. Sin embargo, en Evangelios el llamado es a celebrar la armonía de la pluralidad identitaria en el paisaje, mientras que en Tambores en la noche es una invitación al reconocimiento de la dimensión ancestral afro que asoma en la música y la danza, al mismo tiempo que se recuerda y conmemora la violencia que entraña esta herencia africana en América.

Lo contencioso de la identidad afro tiene como contrapunto en los dos poemarios el escenario hegemónico andino. En Evangelios se hace explícita la necesidad de incorporar en la identidad nacional las expresiones culturales del Pacífico, con el fin de hacer extensiva al territorio nacional la armonía de la pluralidad étnica y racial que se celebra en el Litoral. En Tambores en la noche, en cambio, más que una búsqueda integradora se hace evidente la intención de fracturar el espacio cerrado de herencia europea, para que allí irrumpa el legado negro, con sus danzas, cantos y ritos, haciéndolo visible y, en esta medida, devolviéndole el valor que le fue arrebatado por la violencia colonial.

\section{Referencias}

Artel, Jorge. Tambores en la noche. Bogotá: Ministerio de Cultura, 2010. Digital.

Binns, Niall. "Criaturas del desarraigo, o en busca de los lugares perdidos: alienación y ecología en la poesía hispanoamericana". América Latina Hoy. 30. 2002: 43-77. Digital.

Cabarcas O. Marcelo J. "La figuración poética de la identidad: lo negro en Tambores en la noche de Jorge Artel". Estudios de Literatura colombiana. Ene.-Jun. 2013: 73-86. Digital.

Capote Díaz, Virginia. "En busca de una identidad triétnica y transatlántica. un acercamiento a las tendencias literarias actuales del Pacífico colombiano". Espacios de tránsito. Procesos culturales entre el Atlántico y el Pacífico. Eds. María Isabel Montoya Ramírez y Miguel Ángel Sorroche Cuerva. Granada: Editorial Universitaria, 2014. 57-70. Digital. 
Cifuentes, R. Jaime, comp. Memoria cultural del pacífico. Santiago de Cali: Club de Leones de Buenaventura Monarca, 2002. Digital.

Chevalier, Jean, y Alain Gheerbrant. Diccionario de los Símbolos. Trad. Manuel Silvar y Arturo Rodríguez. Barcelona: Herder, 1986. Impreso.

Curtius, Ernest Robert. "El paisaje ideal". Literatura europea y Edad Media latina. Vol. I. Madrid: Fondo de Cultura Económica, 1995. 263-89. Impreso.

Estupiñán, Juan P. "Marimba en "la nevera": tránsitos sonoros de la música afropacífica colombiana". Revista de Estudos e Investigações Antropológicas. 6.22. 2020: 102-131. Digital.

Forns-Broggi, Roberto. "¿Cuáles son los dones que la naturaleza regala a la poesía latinoamericana?". Hispanic Journal. 19.2. 1998: 209-38. Digital.

Gilard, Jacques. "Colombia, años 40: De El Tiempo a Crítica". América: Cahiers du CR/CCAL. 910. 1992: 219-234. Digital.

Jaramillo, María M. "Mary Grueso Romero: Poesía, Memoria e Identidad”. Chambacú, la historia la escribes tú. Ensayos sobre cultura afrocolombiana. Ed. Lucía Ortiz. Madrid: Iberoamericana; Frankfurt am Main: Vervuert, 2007. 217-232. Impreso.

Jaramillo, María M. "Los alabaos, los arrullos y los chigualos como oficios de difunto y ritos de cohesión social en el Litoral Pacífico colombiano". Inti: Revista de literatura Hispánica. 63. 2006: 277-295. Digital.

LaRosa, Michael J. y Germán Mejía. Historia concisa de Colombia (1810-2013). Bogotá: Ministerio de Cultura, Pontificia Universidad Javeriana, Universidad del Rosario, 2014. Digital.

Lawo-Sukam, Alain. "Acercamiento al concepto de la negritud en la literatura afrocolombiana". Cincinnati Romance Review. 30. 2011: 39-52. Digital.

Lawo-Sukam, Alain. "Nueva Voz: Helcías Martán Góngora y el discurso ecocrítico en la poesía afro-hispana". The Latin Americanist. 52.2. 2008: 23-39. Digital.

Maglia Vercesi, Graciela. "Estéticas de resistencia en la poesía del Caribe afrohispánico". Cuadernos de Literatura. 10.19. 2005: 82-100. Digital.

Mahop Ma Mahop, Romuald Achille. "La lírica de la resistencia en Tambores en la noche de Jorge Artel". Estudios de Literatura Colombiana. 47. 2020: 15-36. Digital. 
Martán Bonilla, Alfonso. "El negro en la poesía de Helcías Martán Góngora". Caribbean Studies 22.3/4. 1989: 57-86. Digital.

Martán Góngora, Helcías. Evangelios del hombre y del paisaje. Humano litoral. Bogotá: Ministerio de Cultura, 2010. Digital.

Mendizábal, Iván R. "La lengua y lo afro: de la literatura oral a la oralitura". Chasqui. Revista Latinoamericana de Comunicación. 120. 2012: 93-102. Digital.

Montemayor, Carlos. Arte y trama en el cuento indígena. Fondo de Cultura Económica. México, 1998. Impreso.

Oliva, María Elena. "Más acá de la negritud: negrismo y negredumbre como categorías de reconocimiento en la primera mitad del siglo XX latinoamericano". Revista CS. 30. 2020: 47-72. Digital.

Omoniyi, Topi. "Language, Race and Identity". The Routledge Handbook of Language and Identity. Ed. Siân Preece. London, New York: Routledge, 2016. 146-62. Impreso.

Ots Capdequí, José María. "Sobre las 'confirmaciones reales' y las 'Gracias al sacar' en la historia del derecho indiano". Estudios de Historia Novohispana. 2.2. 1968: 1-12. Digital.

Preece, Siân. "Introduction". The Routledge Handbook of Language and Identity. Ed. Siân Preece. London, New York: Routledge, 2016. 1-15. Impreso.

Prescott, Laurence. "Evaluando el pasado, forjando el futuro: estado y necesidades de la literatura afro-colombiana". Revista Iberoamericana. LXV.188-189. 1999: 553-65. Digital.

Prescott, Laurence. "Perfil histórico del autor afrocolombiano: problemas y perspectivas". América negra. 12. 1996: 104-25. Digital.

Prescott, Laurence. "Voces del litoral recóndito: tres poetas de la costa colombiana del Pacífico". Estudios colombianos. 26. 2006: 26-36. Digital.

Prescott, Laurence. Without Hatred or Fears. Jorge Artel and the Struggle for Black Literary Expression in Colombia. Detroit: Wayne State University Press, 2000. Impreso.

Real Academia Española. Diccionario de la lengua española [entrada: cholo]. 23. ${ }^{a}$ ed., versión 23.3 (s. f.). Web. <https://dle.rae.es/cholo?m=form>

Restrepo Restrepo, Beatriz. "Piedra y cielo a contraluz". Boletín Cultural y Bibliográfico. 42.69 2005: 24-45. Digital. 
Roth Deubel, André-Nöel. "La génesis del Estado republicano en Colombia: Elementos para una historia social de la administración pública". Cuadernos de Historia del Derecho. 13. 2006: 281-96. Digital.

Rozas, Juan Manuel. La Generación del 27 desde dentro. 2a. ed. Madrid: ISTMO, 1987. Impreso.

Ruíz, lleana. "Duendes y encantos". Periodistas en español. Web. 18 agos. 2013 $<$ https://periodistas-es.com/duendes-y-encantos-25593>

Sandoval, Sergio A. "El canto de la sangre: la música en la poesía de Jorge Artel". Todas las musas. 2. 2011: 204-218. Digital.

de Jesús, Teresa. La vida de la santa madre Teresa de Jesús, y algunas de las mercedes que dios le hizo, escritas por ella misma. Alicante: Biblioteca Virtual Miguel de Cervantes, 2008. Web <http://www.cervantesvirtual.com/nd/ark:/59851/bmc736r9>

UNESCO. Conferencia mundial contra el racismo, la discriminación racial, la xenofobia y las formas conexas de intolerancia. Web. 2001 $<$ https://www.un.org/es/events/pastevents/cmcr/durban_sp.pdf>

Valderrama, Carlos A. "Folclore, raza y racismo en la política cultural e intelectual de Delia Zapata Olivella. El campo político-intelectual afrocolombiano". Revista CS. Trayectorias afrodescendientes. 12. 2013: 259-96. Digital.

Valero, Silvia. "¿De qué hablamos cuando hablamos de "literatura afrocolombiana"? o los riesgos de las categorizaciones." Estudios de Literatura Colombiana. 32. 2013: 15-37. Digital.

Vanín, Alfredo. "La voz del gaviero". Evangelios del hombre y del paisaje. Humano litoral. Helcías Martán Góngora. Bogotá: Ministerio de Cultura, 2010. 11-29. Digital.

Vansina, Jan. La tradición oral. Barcelona: Editorial Labor, 1967. Impreso.

Wabgou, Maguemati. "Herencia negroafricana en Colombia". Contrarelatos desde el sur. 9. 2012: 99-115. Digital. 